\title{
Bioavailability of phosphorus from composts and struvite in acid soils
}

\author{
Carmo Horta ${ }^{1}$ \\ ${ }^{1}$ Instituto Politécnico de Castelo Branco/Escola Superior Agrária/CERNAS, Research Centre for Natural Resources, Environment and Society. Castelo Branco, \\ Portugal. E-mail: carmoh@ipcb.pt (Corresponding author)
}

\section{Key words:}

Olsen P

phosphorus fractionation phosphorus sustainability phosphorus use efficiency

\begin{abstract}
A B S T R A C T
The objective of this study was to assess the type and fractions of phosphorus (P) forms in composts and struvite and how these $\mathrm{P}$ forms affect the bioavailability of $\mathrm{P}$ in the soil. $\mathrm{P}$ fertilization was performed with compost from sewage sludge (CSS), compost from poultry litter (CPL) and struvite (SV) and compared with single superphosphate (SSP). P forms were quantified through a sequential fractionation scheme. The first extraction was performed with $\mathrm{H}_{2} \mathrm{O}$, the second with $0.5 \mathrm{M} \mathrm{NaHCO}_{3}$, the third with $0.1 \mathrm{M} \mathrm{NaOH}$ and the fourth with $1 \mathrm{M} \mathrm{HCl}$. The release of $\mathrm{P}$ over time, after soil $\mathrm{P}$ fertilization, was assessed by incubating the fertilizers with a low-P acid soil. P bioavailability was assessed through a micro-pot experiment with the incubated soils in a growth chamber using rye plants (Secale cereale L.). Inorganic $\mathrm{P}$ forms in the first two fractions represented $~ 50 \%$ (composts), $32 \%$ (SV) and $86 \%$ (SSP) of the total $\mathrm{P}$; and in the $\mathrm{HCl}$ fraction, $~ 40 \%$ (composts), $26 \%$ (SV) and $13 \%$ (SSP) of the total P. Despite the variability of the P form fractions in the composts and struvite, the $\mathrm{P}$ release and bioavailability were similar among the fertilized treatments. The acidic nature of the soil, which improve solubility of Ca-P forms, and the high efficiency of rye, which favors $\mathrm{P}$ uptake, were factors that contributed to these results.
\end{abstract}

\section{Palavras-chave:}

Olsen P

fracionamento do fósforo sustentabilidade do fósforo uso eficiente do fósforo

\section{Biodisponibilidade do fósforo em compostos e struvite aplicados em solos ácidos}

\section{R E S U M O}

O trabalho teve como objetivo caracterizar as formas de fósforo (P) presentes em compostos e em struvite e avaliar a influência dessas formas na biodisponibilidade do P. A fertilização fosfatada efetuou-se com composto obtido de lodos de tratamento de águas residuais (CSS), composto a partir de estrume de galinha (CP) ou struvite (SV) utilizando-se o adubo comercial superfosfato simples (SSP) como controle. Realizou-se um fracionamento sequencial das formas de $\mathrm{P}$ dos fertilizantes: a primeira extração efetuou-se com $\mathrm{H}_{2} \mathrm{O}$, a segunda com $\mathrm{NaHCO}_{3} 0,5 \mathrm{M}$, a terceira com $\mathrm{NaOH} 0,1 \mathrm{M}$ e a quarta com $\mathrm{HCl} 1 \mathrm{M}$. Realizou-se um ensaio de incubação após aplicação de cada fertilizante a um solo ácido e pobre em $\mathrm{P}$ para avaliação do efeito do tempo na libertação do P. A biodisponibilidade de $\mathrm{P}$ foi avaliada num ensaio em vasos com os solos incubados usando como planta teste o centeio (Secale cereale L.). Os compostos apresentaram $~ 50 \%$ do $\mathrm{P}$ inorgânico nas duas primeiras frações, a SV 32\% e o SSP $86 \%$. A fração de $\mathrm{P}$ inorgânico em $\mathrm{HCl}$ representou $\sim 40 \%$ nos compostos, $26 \%$ na SV e $13 \%$ no SSP. Apesar da variabilidade nas formas de P todos os fertilizantes mostraram semelhante taxa de libertação e biodisponibilidade em $\mathrm{P}$. A acidez do solo, favorecendo a solubilização de formas de $\mathrm{P}$, em conjunto com a elevada eficiência do centeio em absorver o P, foram fatores que contribuíram para este resultado. 


\section{INTRODUCTION}

The European Commission included phosphorus (P) in the European Union List of Critical Raw Materials in 2014, emphasizing the need for $P$ reuse and recovery. The extraction of P has significantly decreased phosphate rock resources. Agriculture consumes near $80 \%$ of the world extracted phosphate rock as phosphate fertilizers (CIEC, 2013). This extracted $\mathrm{P}$ ends up in food waste, wastewaters and sewage sludge. Thus, the sustainability of $\mathrm{P}$ fertilization depends on $P$ recovery from such sources, which would contribute to the goals of a circular economy (Withers et al., 2015; George et al., 2016).

Livestock excrete a significant amount of $\mathrm{P}$ in their manures, which goes directly to the soil or to slurry tanks (Kebreab et al., 2013). Livestock slurries and anaerobically digested effluents in wastewaters are good sources of struvite due to their concentration of $\mathrm{N}$ and $\mathrm{P}$. Struvite is a crystalline substance consisting of magnesium, ammonium and phosphorus in equal molar concentrations $\left(\mathrm{MgNH}_{4} \mathrm{PO}_{4} \cdot 6 \mathrm{H}_{2} \mathrm{O}\right)$ that can be used as $\mathrm{P}$ fertilizer or as a raw material for fertilizers (Rahman et al., 2014; Talboys et al., 2016). The use of composts as fertilizers has many advantages over the direct application of sewage sludge and livestock effluents to the soil, since composts are stabilized, have humified organic matter, are free from pathogenic organisms and provide nutrients, including $\mathrm{P}$, to crops (Fuentes et al., 2006; Stutter, 2015).

The origin of the organic waste affects the type and fractions of their $\mathrm{P}$ forms, which may affect $\mathrm{P}$ bioavailability, regardless of the total amount of $\mathrm{P}$ in the compost. (Frossard et al., 2002). Struvite has been considered as an efficient $\mathrm{P}$ fertilizer and it is commonly reported as a slow-release fertilizer, based on the presence of low-solubility P forms (Ackerman et al., 2013; Talboys et al., 2016). This study evaluated the type and fractions of $\mathrm{P}$ forms in struvite and in two composts of different origins. Additionally, the effect of $\mathrm{P}$ form fractions on $\mathrm{P}$ bioavailability was assessed.

\section{Material AND Methods}

This work was conducted at the Instituto Politécnico de Castelo Branco, Portugal, in 2015. Two composts, obtained through aerobic composting of (i) sewage sludge mixed with sawdust (CSS) during 5 months and (ii) poultry litter (CPL) during 3 months, were used. The composts were assessed for their moisture content through the gravimetric method; acidity $(\mathrm{pH})$, with a glass electrode in a suspension of compost and water (1:5, wt/vol); electrical conductivity, in a suspension of compost and water (1:10, wt/vol); organic matter, through the loss of weight after drying at $550{ }^{\circ} \mathrm{C}$ for $16 \mathrm{~h}$; and total $\mathrm{N}$, by the Kjeldahl procedure $\left(\mathrm{N}_{\mathrm{k}}\right)$.

Composts were digested with aqua regia solution $\left(\mathrm{HNO}_{3}+\mathrm{HCl}\right)$ according to the CEN EN 13346:2000 and quantified for their amount $\mathrm{P}$, by molecular absorption spectrophotometry; total cations ( $\mathrm{Fe}, \mathrm{Mn}, \mathrm{Cu}, \mathrm{Pb}, \mathrm{Cd}, \mathrm{Ni}$ and $\mathrm{Cr}$ ), by atomic absorption spectrophotometry; and total $\mathrm{K}, \mathrm{Ca}$, $\mathrm{Mg}$ and $\mathrm{Na}$, by extraction from the hydrochloric acid solution of the ashes. $\mathrm{K}$ and $\mathrm{Na}$ were quantified by flame emission spectrophotometry and $\mathrm{Ca}$ and $\mathrm{Mg}$ by atomic absorption spectrophotometry. $\mathrm{P}$ forms were evaluated by the sequential fractionation scheme of Traoré et al. (1999), using a compost to solution ratio of 1:200 (wt/vol). The first extraction was performed with $\mathrm{H}_{2} \mathrm{O}\left(\mathrm{H}_{2} \mathrm{O}-\mathrm{P}\right)$, the second with $0.5 \mathrm{M} \mathrm{NaHCO}_{3}$ $\left(\mathrm{pH} 8.5 ; \mathrm{NaHCO}_{3}-\mathrm{P}\right)$, the third with $0.1 \mathrm{M} \mathrm{NaOH}(\mathrm{NaOH}-\mathrm{P})$ and fourth with $1 \mathrm{M} \mathrm{HCl}(\mathrm{HCl}-\mathrm{P})$.

The inorganic $\mathrm{P}$ forms $(\mathrm{Pi})$ in water or in the bicarbonate extracts are considered easily available to crops; the Pi extracted in $\mathrm{NaOH}$ solution is mainly bound to $\mathrm{Fe}$ and $\mathrm{Al}$ oxides or metal-organic complexes, and thus considered moderately labile; the $\mathrm{Pi}$ extracted in $\mathrm{HCl}$ is bound mainly to $\mathrm{Ca}$ in low-solubility precipitates, such as apatite or octacalcium phosphate, and thus considered as stable $\mathrm{P}$ forms (Traoré et al., 1999; Gagnon et al., 2012).

Total dissolved $\mathrm{P}$ in the extracts of the first three fractions was analyzed after acid potassium persulpthate digestion (American Public Health Association, 2012) and the dissolved organic P (Po) was calculated as the difference between the total dissolved $\mathrm{P}$ and inorganic $\mathrm{P}$ quantified in each fraction.

The struvite granules used were produced by the NuReSys technology (BIO-STRU ${ }^{\circ}$ ), from the wastewater of the treatment plant of a producer of deep frozen French fries. The composition of this product is $>99 \%$ struvite $\left(\mathrm{NH}_{4} \mathrm{MgPO}_{4} \cdot 6 \mathrm{H}_{2} \mathrm{O}\right)$ with $12 \%$ $\mathrm{P}, 5 \% \mathrm{~N}$ and $10 \% \mathrm{Mg}$. A single superphosphate (SSP) containing $7-9 \%$ of $\mathrm{P}$ was used as the standard mineral fertilizer. The inorganic $\mathrm{P}$ forms of the mineral fertilizers were evaluated using the same procedure used for the composts (Traoré et al., 1999).

A composite soil sample, taken from the layer 0-0.20 m, was air dried and sieved in a $<2 \mathrm{~mm}$-mesh sieve. The soil used was an acidic $\left(\mathrm{pH}_{\mathrm{H}_{2} \mathrm{O}}=5.1\right)$ dystric Regosol, derived from granitic rock, of sandy loam texture ( $8 \%$ clay, $18 \%$ silt and $74 \%$ sand), low cation exchange capacity $\left(4.7 \mathrm{cmol}_{\mathrm{c}} \mathrm{kg}^{-1}\right)$, medium level of organic matter $\left(20 \mathrm{~g} \mathrm{~kg}^{-1}\right)$, low level of Olsen P $\left(7 \mathrm{mg} \mathrm{kg}^{-1}\right)$ and low $\mathrm{P}$ saturation (16\%). The amount of soil used in each replication was $1.5 \mathrm{~kg}$.

The experiment was conducted in a completely randomized design with 5 treatments and 4 replications. The treatments evaluated were Control (C) (without P fertilization), and $\mathrm{P}$ fertilizations with compost from sewage sludge (CSS), compost from poultry litter (CPL), struvite (SV) and single superphosphate (SSP). The struvite and SSP were finely ground to $0.5 \mathrm{~mm}$ and sieved before applying to the soil.

The rate of the composts and mineral fertilizers added to the soil was $13.1 \mathrm{mg}$ of $\mathrm{P}$ per $\mathrm{kg}$ of soil. These fertilizers were mixed with the soil and watered to $70 \%$ of field capacity. This $\mathrm{P}$ rate is recommended for rye production in Regosols in Central Portugal. Unfertilized soils were evaluated as controls under the same conditions in order to estimate the $\mathrm{P}$ from the unfertilized soil. The incubation boxes were placed in an incubator at $25{ }^{\circ} \mathrm{C}$ with absence of light. These boxes were weighed two times a week and watered to maintain the water content at $70 \%$ of field capacity when necessary. During the incubation time (75 days), six samples of each box (replication) were taken at day 0 (beginning of the experiment) and then at every 2 weeks until the end of the experiment. The $\mathrm{P}$ bioavailability of all soil samples were evaluated according to the Olsen method (Olsen et al., 1954; Olsen $\mathrm{P})$. The $\mathrm{P}$ recovery $\left(\mathrm{P}_{\text {rec }}\right)$ by the Olsen test 
was calculated at the end of the incubation period, using the following ratio (units in $\mathrm{mg} \mathrm{kg}^{-1}$ soil):

$$
\mathrm{P}_{\mathrm{rec}}=\left[\frac{(\text { Olsen } \mathrm{P} \text { after fertilization }- \text { Initial Olsen } \mathrm{P})}{\mathrm{P} \text { added to soil }}\right]
$$

Subsequently, $150 \mathrm{~g}$ of soil was taken from each box, placed in pots and mixed with $50 \mathrm{~g}$ of sand in order to improve root growth conditions. Rye (Secale cereale L.) seeds were sown (one plant per pot). These pots were then placed in a growth chamber with photoperiod of $16 \mathrm{~h}$, mean daily temperatures of $24-15^{\circ} \mathrm{C}$, photosynthetically active radiation of $\sim 100 \mu \mathrm{mol} \mathrm{m} \mathrm{m}^{-2} \mathrm{~s}^{-1}$ and $75 \%$ of relative humidity. The pots were watered with the half-strength Hoagland solution without $\mathrm{P}$ during the experiment, totaling $45 \mathrm{mg}$ of $\mathrm{N}$ for the crop. Plants grew over a period of 36 days. Then, the plants were removed from the soil, dried at $65^{\circ} \mathrm{C}$, and weighed to evaluate the plant dry matter. The plant dry matter was ground, sieved in a $0.5-\mathrm{mm}$ mesh sieve and analyzed for total $\mathrm{P}$ after digestion of the ashes with a hydrochloric acid solution $(\mathrm{HCl} 20 \%, \mathrm{v} / \mathrm{v})$. Subsequently, the Olsen $\mathrm{P}$ of the dried soil was evaluated; the result was corrected for the proportion of soil in the mixture. Phosphorus bioavailability was assessed through the plant (i) biomass production (shoot dry matter, $g$ of dry matter per kg of soil), (ii) P uptake (mg of P per kg of soil), and indices used to characterize the $\mathrm{P}$ fertilizer use efficiency (Syers et al., 2008):

Apparent P recovery by $\operatorname{crop}(\%)=\left[\frac{\mathrm{P} \text { uptake }\left(\mathrm{mg} \mathrm{P} \mathrm{kg}^{-1} \text { soil }\right)}{\mathrm{P} \text { added to soil }\left(\mathrm{mg} \mathrm{P} \mathrm{kg}^{-1} \text { soil }\right)}\right] \times 100$

Agronomic efficiency: $\mathrm{AE}(\mathrm{g}$ of $\mathrm{DM}$ per $\mathrm{mg}$ of $\mathrm{P}$ applied to soil $)=\left[\frac{(\mathrm{Yn}-\mathrm{Yc})}{\mathrm{Pn}}\right]$

in which $\mathrm{Y}$ is the biomass production ( $\mathrm{g} \mathrm{kg}^{-1}$ soil) with $\left(\mathrm{Y}_{\mathrm{n}}\right)$ or without $\left(\mathrm{Y}_{\mathrm{c}}\right) \mathrm{P}$ fertilization and $\mathrm{P}_{\mathrm{n}}$ is the amount of $\mathrm{P}$ applied ( $\mathrm{mg} \mathrm{kg}^{-1}$ soil).

Statistical analysis of the data (Olsen P, rye biomass, $\mathrm{P}$ uptake, apparent $\mathrm{P}$ recovery and agronomic efficiency) were performed by one-way ANOVA with five treatments using the software IBM-SPSS Statistics 21 . Tukey's test was used to identify differences between means at $\mathrm{p}<\alpha=0.05$ probability level.

\section{Results AND Discussion}

The chemical properties of the composts tested varied (Table 1), which was mainly due to their origin. However, both composts could be classified as fertilizers, due to their overall properties, according to the EC regulation CE No. 2003/2003 and the Portuguese normative DL No.103/2015. Both composts had less than $40 \%$ moisture content, more than $30 \%$ of organic matter and $\mathrm{pH}$ of 5.5 to 9.0. Thus, they were classified as Class II, i.e., suitable to use as fertilizers in agriculture, and can be applied annually at a maximum amount of $25 \mathrm{Mg} \mathrm{ha}^{-1}$. The compost from poultry litter (CPL) had higher contents of $\mathrm{P}$, $\mathrm{K}, \mathrm{Ca}, \mathrm{Na}$ and $\mathrm{Fe}$ than the compost from sewage sludge (CSS), which is related to the poultry diet compositions. These high levels of nutrients in the CPL could explain its higher $\mathrm{pH}(9.0)$ and EC ( $\left.6.04 \mathrm{dS} \mathrm{m}^{-1}\right)$ compared with the CSS (8.5 and $2.10 \mathrm{dS} \mathrm{m}^{-1}$, respectively). The $\mathrm{N}$ content was similar in both composts. The C:N ratio were within the range found in several works on composts, less than 20 (13 for CSS and and 19 for CPL), which is an indicator of compost maturity (Ko et al., 2008). The N:P ratios of both composts ( 1 for CPL and 4 for CSS) showed risk of over fertilization of $\mathrm{P}$, since $\mathrm{N}: \mathrm{P}$ ratios for this crop are within 4.5 and 9.1.

The total amount of $\mathrm{P}\left(\mathrm{P}_{\mathrm{t}}, \mathrm{g} \mathrm{kg}^{-1}\right.$ dry matter $)$ was 4.5 for CSS, 18.8 for CPL, 121 for SV and 94 for SSP (Table 2). Inorganic $\mathrm{P}(\mathrm{Pi})$ forms in the composts represented about $90 \%$ of the $\mathrm{P}_{\mathrm{t}}$, with residual $\mathrm{P} \leq 1 \%$. The $\mathrm{Pi}$ fractions in the four sequential fractionations showed high variability between the composts (CSS and CPL) and between the mineral fertilizers (SV and SSP). The sequential fractionation of $\mathrm{Pi}$ forms in CSS was $\mathrm{NaHCO}_{3}>\mathrm{HCl}>\mathrm{H}_{2} \mathrm{O}>\mathrm{NaOH}$, while in $\mathrm{CPL}$ was $\mathrm{HCl}>\mathrm{H}_{2} \mathrm{O}$ $>\mathrm{NaHCO}_{3}>\mathrm{NaOH}$. In the first two more labile fractions, the $\mathrm{Pi}$ in the CSS and CPL represented 54 and $46 \%$ of the total P, respectively. The $\mathrm{HCl}-\mathrm{Pi}$ fraction (a more stable $\mathrm{P}$ form) of the

Table 2. Inorganic and organic fractions of $\mathrm{P}$ in composts and inorganic fractions of $\mathrm{P}$ in mineral fertilizers

\begin{tabular}{|c|c|c|c|c|}
\hline \multirow{2}{*}{$P$ form } & CSS & $\overline{C P L}$ & SV & SSP \\
\hline & \multicolumn{4}{|c|}{$P$ concentration $\left(\mathrm{mg} \mathrm{kg}^{-1}\right)$} \\
\hline \multicolumn{5}{|l|}{ Inorganic P } \\
\hline Water & 773 & 5957 & 4931 & 75617 \\
\hline Bicarbonate & 1674 & 2536 & 33982 & 5571 \\
\hline Hydroxide & 305 & 1167 & 50817 & 283 \\
\hline Acid & 1371 & 7475 & 31089 & 12636 \\
\hline \multicolumn{5}{|l|}{ Organic $P$} \\
\hline Water & 68 & 981 & & \\
\hline Bicarbonate & 61 & 255 & & \\
\hline Hydroxide & 163 & 369 & & \\
\hline Inorganic $P$ & 4123 & 17134 & 120819 & 94107 \\
\hline Organic $P$ & 292 & 1604 & & \\
\hline Residual P & 64 & 93 & & \\
\hline Total P & 4479 & 18833 & 120819 & 94107 \\
\hline
\end{tabular}

CSS - Sewage sludge compost; CPL - Poultry compost; SV - Struvite; SSP - Single superphosphate

Table 1. Characteristics of the compost from sewage sludge (CSS) and compost from poultry litter (CPL) used in the experiment

\begin{tabular}{|c|c|c|c|c|c|c|c|c|c|c|}
\hline \multirow{2}{*}{ Properties ${ }^{1}$} & DM & OM & \multirow{2}{*}{$\mathrm{pH}$} & \multirow{2}{*}{$\begin{array}{l}\text { Electrical conductivity } \\
\qquad \mathrm{dS} \mathrm{\textrm {m } ^ { - 1 }}\end{array}$} & $N_{k}$ & $\mathbf{P}$ & K & $\mathrm{Ca}$ & \multirow{2}{*}{ C:N } & \multirow{2}{*}{$\mathrm{N}: \mathrm{F}$} \\
\hline & \multicolumn{2}{|c|}{$\mathrm{g} \mathrm{kg}^{-1}$} & & & \multicolumn{4}{|c|}{$\mathrm{g} \mathrm{kg}^{-1} \mathrm{DM}$} & & \\
\hline CSS & 615 & 397 & 8.5 & 2.10 & 17.6 & 4.5 & 16.9 & 142 & 13 & 4 \\
\hline \multirow[t]{3}{*}{$\mathrm{CPL}$} & 795 & 564 & 9.0 & 6.04 & 17.1 & 18.8 & 51.8 & 384 & 19 & 1 \\
\hline & $\mathrm{Mg}$ & $\mathrm{Na}$ & $\mathrm{Fe}$ & Mn & & & & Cd & $\mathrm{Ni}$ & $\mathrm{Cr}$ \\
\hline & \multicolumn{3}{|c|}{$\mathrm{g} \mathrm{kg}^{-1} \mathrm{DM}$} & \multicolumn{7}{|c|}{$\mathrm{mg} \mathrm{kg}^{-1} \mathrm{DM}$} \\
\hline CSS & 19.2 & 3.47 & 4.3 & 1084 & & & & $<0.04$ & 57 & 112 \\
\hline CPL & 13.1 & 78.70 & 24.2 & 470 & & & & $<0.04$ & 9 & 8 \\
\hline
\end{tabular}

DM - Dry matter; OM - Organic matter 
CSS and CPL composts represented 31 and $40 \%$ of the total $\mathrm{P}$, respectively.

These results were similar to those found by Gagnon et al. (2012), however, Sharpley \& Moyer (2000) found similar $\mathrm{Pi}$ in the first two fractions in CPL (52\%), but found a lower percentage of $\mathrm{Pi}$ for the $\mathrm{HCl}$ fraction (27\%). This difference can be attributed to the lower Ca content of the CPL or to the lower composting time (2 months) compared with that used in the present work (5 months).

The different fractions of Pi forms in the two composts are probably due to their different origin and composition, which resulted in different $\mathrm{P}$ transformations, binding Pi to different cations during the composting time (Fuentes et al., 2006).

CPL is derived from organic waste, which is rich in Ca due to the poultry diets, thus, it showed a high rate of $\mathrm{Pi}$ in the $\mathrm{HCl}$ extraction (Table 2). Traoré et al. (1999) found an increase of $\mathrm{Pi}$ in $\mathrm{HCl}$ fraction in CSS during composting and attributed this result to the increase in precipitated forms of $\mathrm{Ca}$ or $\mathrm{Mg}$ phosphates. However, in composts from other origins (house refuse and food waste), these authors observed an increase in $\mathrm{Pi}$, mainly in the $\mathrm{NaOH}$ and $\mathrm{NaHCO}_{3}$ fractions, and attributed this result to the $\mathrm{Pi}$ binding to $\mathrm{Fe}$ and $\mathrm{Al}$ complexes. The $\mathrm{NaOH}-\mathrm{P}$ of the composts evaluated in the present work was the smallest fraction, which is consistent with their lower contents of Fe compared with the content of $\mathrm{Ca}$ in both CSS and CPL (Table 1). The fraction of organic $\mathrm{P}$ ( $\mathrm{Po}$ ) forms in relation to the total $\mathrm{P}$ in $\mathrm{CSS}$ was $\mathrm{NaOH}>\mathrm{H}_{2} \mathrm{O}>\mathrm{NaHCO}_{3}$, and in $\mathrm{CPL}$ was $\mathrm{H}_{2} \mathrm{O}>\mathrm{NaOH}>\mathrm{NaHCO}_{3}$. The low level of Po in the dry matter of both composts $\left(292 \mathrm{mg} \mathrm{Po} \mathrm{kg}^{-1}\right.$ in CSS and $1604 \mathrm{mg} \mathrm{Po} \mathrm{kg}^{-1}$ in CPL) showed a little significance of $\mathrm{Po}$ as a source of $\mathrm{P}$ for crop nutrition.

The Pi fractions of the mineral fertilizers analyzed varied (Table 2). The main forms of $\mathrm{P}$ in the struvite, quantified in the $\mathrm{NaHCO}_{3}(28 \%)$ and $\mathrm{HCl}(26 \%)$ fractions were bound to $\mathrm{Mg}$ or $\mathrm{Ca}$. Moreover, the content of $\mathrm{Pi}$ in the $\mathrm{NaOH}$ fraction (42\%) indicates some precipitation of $\mathrm{P}$ with other metals, such as $\mathrm{Fe}$ and $\mathrm{Mn}$. On the other hand, $\mathrm{H}_{2} \mathrm{O}-\mathrm{P}$ was the most representative $\mathrm{Pi}$ fraction (80\%) in SSP, and the $\mathrm{Pi}$ of the $\mathrm{HCl}$ fraction accounted for $13 \%$ of the total P. These results are consistent with the SSP manufacturing process of reaction of phosphate rock with sulfuric acid.

The Olsen $\mathrm{P}$ in the fertilized treatments was 12 to $19 \mathrm{mg} \mathrm{kg}^{-1}$ at the beginning of the experiment, regardless of the fertilizer used (Table 3). These results put these soils in the medium fertility class, according to Portuguese standards.

The fluctuations in Olsen $\mathrm{P}$ throughout the incubation time indicate that the composts and struvite were releasing their $\mathrm{P}$ at a rate similar to the SSP (Table 3). The struvite had the highest increase of Olsen P compared to the other fertilizers. Consequently, the $\mathrm{P}$ recovery by the Olsen test, in relation to the $\mathrm{P}$ added to soil (Eq. 1), was significantly higher ( $\mathrm{p} \leq 0.05)$ in soils treated with struvite (0.76) than with SSP (0.66), CPL (0.50) and CSS (0.48). The higher P recovery obtained in SV indicates a probably higher solubilization of $\mathrm{P}$ forms compared with the compost treatments. Moreover, the fact that the SV and SSP were finely ground before application to the soil, increasing their specific surface area and thus improving their reactivity, could explain these results.

The Olsen-P of all fertilized treatments decreased in the first month after soil fertilization (Table 3 ), which was probably due to $\mathrm{P}$ sorption onto the soil solid phase, since the initial Olsen $\mathrm{P}$ of the soil was very low and the $\mathrm{P}$ sorption complexes were undersaturated (P saturation of $16 \%$ ). However, the increase of Olsen $\mathrm{P}$ throughout the incubation time indicates that low $\mathrm{pH}$ favors the dissolution of Ca-P forms.

The $\mathrm{P}$ fertilization significantly increased the plant biomass production $(\mathrm{p} \leq 0.01)$ and $\mathrm{P}$ uptake $(\mathrm{p} \leq 0.001)$, regardless of the fertilizer used. The fertilization almost doubled the rye biomass and almost tripled the P uptake (Table 4).

The Olsen $\mathrm{P}$ at the beginning of the crop cycle was within the adequate range for the crop (Table 3 , day 75). This result explains the similarity in P bioavailability in the fertilized treatments. Some authors reported different rates of $\mathrm{P}$ released from struvite due to edaphic properties and crop characteristics,

Table 3. Olsen $\mathrm{P}\left(\mathrm{mg} \mathrm{kg}^{-1}\right.$ soil) of all treatments during the incubation time

\begin{tabular}{lccccccc}
\hline \multirow{2}{*}{ Treatments } & \multicolumn{9}{c}{ Sampling days } & \multicolumn{2}{c}{$\begin{array}{c}\text { Significance } \\
\text { level }\end{array}$} \\
\cline { 2 - 6 } Control & $\mathbf{0}$ & $\mathbf{1 5}$ & $\mathbf{3 0}$ & $\mathbf{4 5}$ & $\mathbf{6 0}$ & $\mathbf{7 5}$ & $\mathrm{p}>0.05$ \\
$\mathrm{CSS}$ & $6.8 \mathrm{C}$ & $6.6 \mathrm{~d}$ & $6.6 \mathrm{~d}$ & $6.8 \mathrm{~d}$ & $6.7 \mathrm{~d}$ & $6.9 \mathrm{c}$ & $\mathrm{p} \leq 0.01$ \\
$\mathrm{CPL}$ & $11.8 \mathrm{bAB}$ & $10.3 \mathrm{cB}$ & $9.8 \mathrm{Cb}$ & $10.5 \mathrm{cB}$ & $12.3 \mathrm{cAB}$ & $13.2 \mathrm{bA}$ & $\mathrm{p}$ \\
SV & $12.2 \mathrm{bAB}$ & $11.9 \mathrm{cbB}$ & $11.8 \mathrm{cbB}$ & $13.0 \mathrm{bAB}$ & $15.5 \mathrm{bA}$ & $13.4 \mathrm{bAB}$ & 0.05 \\
SSP & $19.3 \mathrm{aA}$ & $14.2 \mathrm{aB}$ & $16.8 \mathrm{Aab}$ & $15.7 \mathrm{aAB}$ & $17.7 \mathrm{aAB}$ & $16.9 \mathrm{aAB}$ & $\mathrm{p} \leq 0.01$ \\
Significance level & $16.8 \mathrm{a}$ & $13.5 \mathrm{ab}$ & $14.4 \mathrm{ab}$ & $15.5 \mathrm{a}$ & $17.4 \mathrm{ab}$ & $15.6 \mathrm{ab}$ & $\mathrm{p}>0.05$ \\
\hline
\end{tabular}

Means followed by different lowercase letters in the columns and means followed by different uppercase letters in the rows were significantly different

Means followed by different letters in columns were significantly different

Table 4. Plant biomass, $\mathrm{P}$ uptake, apparent $\mathrm{P}$ recovery and agronomic efficiency of rye (Secale cereale L.) under different $P$ fertilization treatments

\begin{tabular}{|c|c|c|c|c|}
\hline Treatments & $\begin{array}{c}\text { Rye biomass } \\
\mathrm{g} \mathrm{kg}^{-1} \text { soil }\end{array}$ & $\begin{array}{c}\mathrm{P} \text { uptake } \\
\mathrm{mg} \mathrm{kg}^{-1} \text { soil }\end{array}$ & Apparent $\mathrm{P}$ recovery (\%) & $\begin{array}{c}\text { Agronomic efficiency } \\
\left(\mathrm{g} \mathrm{g} \mathrm{g}^{-1}\right)\end{array}$ \\
\hline Control & $0.72 \mathrm{~b}$ & $1.5 \mathrm{~b}$ & & \\
\hline CSS & $1.35 \mathrm{a}$ & $4.4 \mathrm{a}$ & 34 & 48 \\
\hline $\mathrm{CPL}$ & $1.20 \mathrm{a}$ & $4.7 \mathrm{a}$ & 36 & 39 \\
\hline SV & $1.20 \mathrm{a}$ & $4.4 \mathrm{a}$ & 34 & 42 \\
\hline SSP & $1.36 \mathrm{a}$ & $3.5 \mathrm{a}$ & 27 & 50 \\
\hline Significance level & $p \leq 0.01$ & $p \leq 0.001$ & $p>0.05$ & $p>0.05$ \\
\hline
\end{tabular}

Means followed by different letters in columns were significantly different

$\mathrm{CSS}=$ Compost from sewage sludge; $\mathrm{CPL}=$ Compost from poultry litter; SV = Struvite; SSP = Single superphosphate 
such as root exudates (González-Ponce et al., 2009; Ackerman et al., 2013; Katanda et al., 2016; Talboys et al., 2016). Ackerman et al. (2013) found lower production of biomass per unit of $\mathrm{P}$ from struvite, compared with MAP and PCMAP, due to a lower initial solubility of struvite in the alkaline soil used. Similarly, González-Ponce et al. (2009) found a higher lettuce yield due to the beneficial effects of $\mathrm{Mg}$ content of struvite compared with SSP treatments. Moreover, according to Talboys et al. (2016), the presence of high amounts of organic acids exuded by buckwheat roots (Fagopyrum esculentum Moench) improves the P solubility of struvite, compared with T. aestivum, which did not exude large quantities of organic acids.

The high $\mathrm{P}$ uptake and use efficiency of rye, as also observed by Osborne \& Rengel (2002), partially explains the use of $\mathrm{P}$ from forms of lower availability (Kochian et al., 2004). In addition, the low soil pH (5.1), which favors the dissolution of $\mathrm{Ca}-\mathrm{P}$ or $\mathrm{Mg}-\mathrm{P}$ forms, explains the similar results of $\mathrm{P}$ bioavailability of all fertilized treatments. According to Frossard et al. (2002), alkaline composts, as those evaluated in the present work, have slightly soluble and poorly crystallized Ca-P compounds that may have low availability to plants in neutral and alkaline soils (Fardeau et al., 1988), which was not the case of the soil used in the present work.

Regarding the complementary indices of $\mathrm{P}$ use efficiency (apparent $\mathrm{P}$ recovery and agronomic efficiency), the fertilized treatments showed no significant differences (Table 4). The agronomic efficiency ranged from $50 \mathrm{~g} \mathrm{~g}^{-1}$ in the SSP to $32 \mathrm{~g} \mathrm{~g}^{-1}$ in the CPL treatment, and the apparent $\mathrm{P}$ recovery ranged from $\sim 35 \%$ in CSS, CPL and SV treatments to $27 \%$ in SSP. These results were lower than those reported by Syers et al. (2008) for an entire crop cycle, but higher than those found by Talboys et al. (2016) on T. aestivum for struvite (11\%).

\section{Conclusions}

1. The fractions of $\mathrm{P}$ forms varied among the fertilizers, however, the composts and struvite showed similar ability to provide $\mathrm{P}$ to plants in acid soils to the single superphosphate.

2. Almost $90 \%$ of the total $\mathrm{P}$ found in the composts evaluated was in inorganic forms.

3. The decrease in Olsen P, which occurs soon after fertilization, can be overcome through the use of composts for soil fertilization, applied at least one month before seeding, and struvite, applied at least two weeks before seeding.

\section{Acknowledgement}

This work was funding by the Portuguese Foundation for Science and Technology (FCT) (Project UIID/ $\mathrm{AMB} / 00681 / 2013)$.

\section{Literature Cited}

Ackerman, J. N.; Zvomuya, F.; Cicek, N.; Flaten, D. Evaluation of manure derived struvite as a phosphorus source for canola. Canadian Journal of Plant Science, v.93, p.419-424, 2013. https:// doi.org/10.4141/cjps2012-207

American Public Health Association. Standard methods for the examination of water and wastewater. 22.ed. 2012. p.4148-4152.
CIEC. The essential chemical industry on line. 2013. <http://www. essentialchemicalindustry.org/chemicals/phosphoric-acid.html.> Accessed in 27 Jul. 2016.

Fardeau, J.-C.; Morel, C.; Jahiel, M. Does long contact with the soil improve the efficiency of rock phosphate? Results of isotopic studies. Fertilizer Research, v.17, p.3-19, 1988. https://doi.org/10.1007/BF01050453

Frossard, E.; Skrabal, P.; Sinaj, S.; Bangerter, F.; Traoré, O. Forms and exchangeability of inorganic phosphate in composted solid organic wastes. Nutrient Cycling in Agroecossystems, v.62, p.103-113, 2002. https://doi.org/10.1023/A:1015596526088

Fuentes, B.; Bolan, N.; Naidu, R.; Mora, M. de la L. Phosphorus in organic waste-soil systems. Journal of Soil Science and Plant Nutrition, v.6, p.64-83, 2006. https://doi.org/10.4067/s0718-27912006000200006

Gagnon, B.; Demers, I.; Ziadi, N.; Chantigny, M. H.; Parent, L.-E.; Forge, T. A.; Larney, F. J.; Buckley, K. E. Forms of phosphorus in composts and in compost-amended soils following incubation. Canadian Journal of Soil Science, v.92, p.711-721, 2012. https:// doi.org/10.4141/cjss2012-032

George, T. S.; Hinsinger, P.; Turner, B. L. Phosphorus in soils and plants - Facing phosphorus scarcity. Plant and Soil, v.401, p.1-6, 2016. https://doi.org/10.1007/s11104-016-2846-9

González-Ponce, R.; López-de-Sá, E. G.; Plaza, C. Lettuce response to phosphorus fertilization with struvite recovered from municipal wastewater. HortScience, v.44, p.426-430, 2009.

Katanda, Y.; Flaten, D. F. Z.; Cicek, N. Hog-manure-recovered struvite: Effects on canola and wheat biomass yield and phosphorus use efficiencies. Soil Science Society of America Journal, v.80, p.135146, 2016. https://doi.org/10.2136/sssaj2015.07.0280

Kebreab, E.; Hansen, A. V.; Leytem, A. B. Feed management practices to reduce manure phosphorus excretion in dairy cattle. Advances in Animal Biosciences, v.4, p.37-41, 2013. https://doi.org/10.1017/ S2040470013000290

Ko, H. J.; Kim, K. Y.; Kim, H. T.; Kim, C. N.; Umeda, M. Evaluation of maturity parameters and heavy metal contents in composts made from animal manure. Waste Management, v.28, p.813-820, 2008. https://doi.org/10.1016/j.wasman.2007.05.010

Kochian, L. V.; Hoekenga, O. A.; Piñeros, M. A. How do crop plants tolerate acid soils? Mechanisms of aluminum tolerance and phosphorous efficiency. Annual Review of Plant Biology, v.55, p.459-493, 2004. https://doi.org/10.1146/annurev.arplant.55.031903.141655

Olsen, S.; Cole, C.; Watanabe, F.; Dean, L. Estimation of available phosphorus in soils by extraction with sodium bicarbonate. Washington: United States Department of Agriculture, 1954. 19p. Circular 939

Osborne, L. D.; Rengel, Z. Screening cereals for genotypic variation in efficiency of phosphorus uptake and utilisation. Australian Journal of Agricultural Research, v.53, p.295-303, 2002. https:// doi.org/10.1071/AR01080

Rahman, M. M.; Salleh, M. A. M.; Rashid, U.; Ahsan, A.; Hossain, M. M.; Ra, C. S. Production of slow release crystal fertilizer from wastewaters through struvite crystallization - A review. Arabian Journal of Chemistry, v.7, p.139-155, 2014. https://doi. org/10.1016/j.arabjc.2013.10.007

Sharpley, A.; Moyer, B. Phosphorus forms in manure and compost and their release during simulated rainfall. Journal of Environmental Quality, v.29, p.1462-1469, 2000. https://doi.org/10.2134/ jeq2000.00472425002900050012x

Stutter, M. I. The composition, leaching, and sorption behavior of same alternative sources of phosphorus for soils. Ambio, v.44, p.S207-S216, 2015. https://doi.org/10.1007/s13280-014-0615-7 
Syers, J. K.; Johnston, A. E.; Curtin, D. Efficiency of soil and fertilizer phosphorus use. Reconciling changing concepts of soil phosphorus behaviour with agronomic information. Fertilizer and Plant Nutrition Bulletin 18 Rome: FAO, 2008. 108p.

Talboys, P. J.; Heppell, J.; Roose, T.; Healey, J. R.; Jones, D. L.; Withers, P. J. A. Struvite: A slow-release fertiliser for sustainable phosphorus management? Plant and Soil, v.401, p.109-123, 2016. https://doi.org/10.1007/s11104-015-2747-3
Traoré, O.; Sinaj, S.; Frossard, E.; Kerkhove, J. M. van de. Effect of composting time on phosphate exchangeability. Nutrient Cycling in Agroecossystems, v.55, p.123-131, 1999. https://doi. org/10.1023/A:1009828927161

Withers, P. J. A.; Dijk, K. C. van; Neset, T.-S. S.; Nesme, T.; Oenema, O.; Rubæk, G. H.; Schoumans, O. F.; Smit, B.; Pellerin, S. Stewardship to tackle global phosphorus inefficiency: The case of Europe. Ambio, v.44, p.193-206, 2015. https://doi.org/10.1007/s13280-014-0614-8 